\title{
Technology as an Assessment Tool in Language Learning
}

\author{
Taher Bahrani \\ Department of English, Mahshahr Branch, Islamic Azad University, Mahshahr, Iran \\ E-mail: taherbahrani@yahoo.com
}

Received: May 8, 2011 Accepted: June 13, 2011 doi:10.5539/ijel.v1n2p295

\begin{abstract}
The present paper examines the employment of different technology-based tools such as computer, podcast, and chat for assessing language proficiency in EFL classrooms. These methods which are referred to as alternative assessments differ from traditional paper-and-pencil assessments. The technology-based assessment incorporates innovative methods and techniques to measure language proficiency improvement. This kind of assessment is effective when it gives the language learners a chance to use what they have learnt. On the contrary, traditional methods of assessment fail to show what learners can do with their acquired language. This paper aims at illustrating several activities that teachers can use with the help of technology to measure and monitor their students' achievements in language learning.
\end{abstract}

Keywords: Technology-based, Assessment, Language proficiency, Achievement

\section{Introduction}

According to many scholars in the field of language testing, a successful assessment of different language skills should be highly authentic, valid, and reliable enough to be used (Hatch and Farhadi, 1982; Hughes, 2003; Creswell, 2003).

Authenticity in general refers to real world activities. Accordingly, if a test is supposed to be authentic, it should reflect the real world activities. As a matter of fact, the activities which are used in testing should not be artificial such as matching items. They should reflect on the communicative aspects of the language in real world communication.

Validity means that the assessment should test what it is supposed to test. The content of the test is one kind of validity which should reflect the purpose of the test.

The last but not the least important factor in testing is reliability which generally refers to the consistency of the scores. In his regard, the traditional methods of testing such as multiple-choice, which are still used by many teachers, often lack authenticity and validity because they do not represent how we use the language for communication with other people in informal setting outside the classrooms (Underhill, 1987). In other word, they are rather artificial than real.

Considering these issues, a set of technology-based assessment methods which are presented below can help language teachers in measuring what their students have learnt to be used in real world communication. The important point to highlight regarding the following methods is that they underline students' creativity and self-assessment in EFL classrooms which cannot be found in traditional methods of testing.

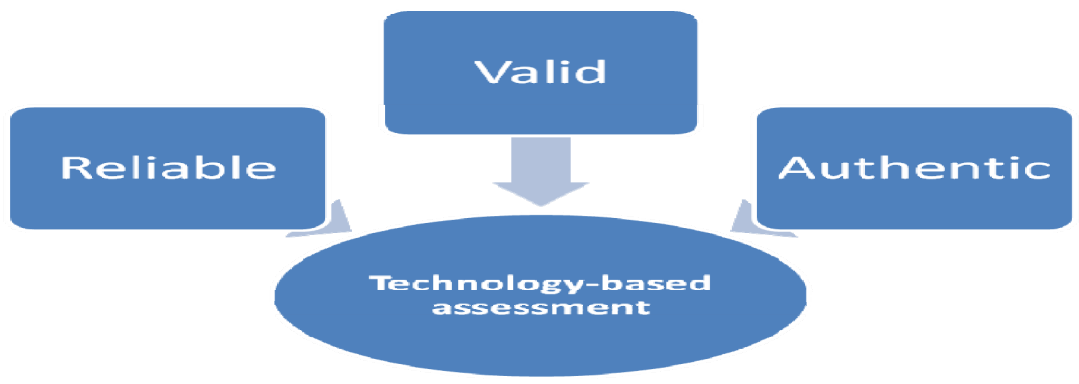




\section{Technology-based assessments}

Today, different technologies have dominated the world by impressive developments. These developments have made different technologies to be used in different aspects of language teaching such as language testing.

In view of that, different technologies can be used to help the teachers assess their students' language proficiency in general and different language skills in particular without having to be dependent on traditional methods of testing which may not reveal the exact achievement of different skills. In this regard, several factors should be considered by those teachers who aim at designing assessment based on technology:

- Does the activity require the student to be creative?

- Does the activity reflect real world communication?

- Does the activity let the student use what he/she has learnt?

- Does the activity allow the student to use their language skills as a whole?

- Does the activity increase motivation?

- Does the activity reduce the affective filter?

- Does the activity increase group work?

- Is the activity reliable enough?

- Is the activity valid?

- Is the activity authentic?

Consequently, any activity to be designed to assess different language skills via the utilization of different technologies should require the students to be creative. To do this end, the activity should reflect real world communication. In other words, it should reflect on what the language learners may face within the society.

Another essential factor in designing technology based assessment is that the activity should let the students use what he/she has learnt. Some teachers design some tests looking for what the students do not know rather than what they have learnt.

The activities should also reduce the affective filter and increase the motivation. Sometimes, this can be achieved by giving the floor to the language learners themselves to design some assessment activities for their peers. In this regard, teachers can divide the class into two groups and ask each group to design some test items for the other group. This will increase the motivation.

The last but not the least important issue to be considered after designing the activities is verification of the items. In fact, the reliability and the validity of the test should be verified. This can be achieved by running a pilot study to make the necessary amendments.

Considering the above-mentioned questions, different technologies such as computer, the internet, mobile phones, and chat can be valuable sources not only for language learning but also for assessing different language skills.

Following are some computer-assisted, mobile-assisted, and sound recorders activities that can be used both in formal and in informal language learning settings. They can also be used to assess the language learners' progress.

\subsection{Podcast}

Podcasts are best used for practicing and improving listening comprehension. However, they can also be used for improving other language skills such as speaking proficiency. In this regards, students can go to some websites which enable them to record and upload their own voices. Then, other students can easily have access to the recorded clips. Accordingly, they can then leave some comments regarding what they hear. These comments will help language learners to know about their weakness. Following, the teacher can score the students accordingly. This way, the students are free to talk about any topic which they have information about. They can talk about any topic which they like. So, they are not limited to what the teacher wants. The affective filter will also be decreased.

In order to increase the validity of the scoring, the scoring criteria should be developed which correspond with the course objectives.

Another activity which can be given to the students is a project. Accordingly, a project is given to a group of language learners to work on outside the classroom atmosphere. Then, the students in the same group should 
report the outcome to the teacher. However, teachers should bear in mind the language proficiency level and the interest of the participants. In other words, teachers should not impose a topic to a group which is above the language proficiency level of the students. To avoid introducing linguistically inappropriate topics to the language learners, teachers can ask the language learners about their preferences. Among the topics which the language learners offer, teachers can select one.

In relation to the sorts of activities which can be used through the application of different technologies such as podcast, it should be emphasized that various activities can be used which may seem to be traditional at the first glance. However, the important point is that the outcome of any activity given to the students should be shared with other students through podcasting.

\subsection{Chat}

Today, many web 2.0 sites offer free online chatting service which can be pedagogically valuable for language learning as well as language assessment. In the same line, the role of social networking sites like Twitter and Facebook known as Web 2.0 in language learning has been investigated by some researchers (O'Reilly, 2005; Brown, 2008; Hall, 2008; Friesen, 2007; Siemens, 2005; Mason, 2008; Warschauer, 1996; Chun, 1994; Kern, 1995; just to name some).

Accordingly, the term "Web 2.0" refers to web applications that facilitate participatory information sharing by user-centered design and collaboration on the World Wide Web (O'Reilly, 2005). A web 2.0 site allows users to interact and collaborate with each other in a social media dialogue in contrast to websites where users are limited to the passive viewing of content .

Web 2.0 sites offer possibilities for increasing ability for communication, self-expression and learning (Hall, 2008). According to Brown (2008), services like Facebook and twitter provide a range of communicative modes for the development of online communities. These new communicative technologies and forms are characterized by minute or micro-sized pieces of text or information (Friesen, 2007), socially-oriented interactions (Mason 2008), and the development of myriad connections between and among users and resource (Siemens, 2005).

According to many studies conducted regarding the use of chat for language learning, chat conversations for one hour a day can improve speaking proficiency to a significant extent (Warschauer, 1996; Chun, 1994; Kern, 1995). Shy students are those who benefit more from chat room. However, the important point to mention here is that the chat conversation can be beneficial if it is conducted orally not in the written form. If chatting with other students in other countries is not possible, language learners can chat with their peers.

Teachers can raise a topic in the classroom every week and asks the students to join different chatrooms and exchange ideas with their classmates or other students. In relation to the topic selection criteria, teachers should consider the students' language proficiency level and interest.

\subsection{Mobile phones}

In relation to the use of various technologies that can provide quick access to authentic language input in informal language learning setting, mobile phones now have the emerging potential to achieve a large scale impact in language learning and language testing because of their portability, versatile features, and low cost (Roschelle, 2003). Rapid advancements in information and communication technology have together made this potential of mobile phones to a great extent possible.

In this regard, emerging technologies such as mobile phones need to be fully interpreted and applied according to the environment in which they will operate, being well aware of their limitations and challenges, bearing in mind their potential impact on transforming current cultures and practices (Cobcroft et al. 2006).

In the same line, today almost every student has one mobile phone. Many students spend many hours on the phone per week talking with their classmates about school things or other things. If the students are encouraged by the teachers to hold these conversations in English rather that their first language, the students can improve their language proficiency a lot. Teachers can also ask the students to record their conversation and bring it to the classroom to be assessed by the teacher or the other students. Students may find it difficult to achieve this purpose at first. However, as they do this over and over, they will arrive at the pedagogical value of holding their conversations in English. Moreover, they will find so many things in common with other peers to talk about in English.

\subsection{Interview and role play}

At the first glance, interview and role play seem to be traditional. However, the point is that the students can choose a topic and interview other students about it. If the interview is recorded by a camera or a mobile phone, 
it can be viewed and assessed later by the teacher. However, the teacher can encourage the students to listen to the recorded interview and rerecord it if they find their problems before they give it to the teacher. They can also ask their peers to listen to their conversations and evaluate them. This way, the teacher can increase the students self-monitoring which is generally understood to help language learning.

\section{Conclusion}

The main objective of the present paper was to introduce some activities which can be incorporated with various technologies that can be utilized not only for language learning but also for language assessment. Accordingly, teachers can use computers, the internet technology, and mobile phones to encourage language learning and language assessment. However, teachers should be aware of these assessment methods via technology to assess the students' language proficiency.

In this regard, the important point to underline is that any methods to be used for language testing with the employment of any technologies including mobile phones should be authentic, valid, and reliable. Moreover, the activities should also be based on the students' interest. By using the technology, teachers can make a connection between language assessment and real world communication.

\section{References}

Brown, L. (2008). Student faces Facebook consequences. Toronto Star. [Online] Available: http://www.thestar.com/News/GTA/article/309855 (June 10, 2011).

Chun, D. M. (1994). Using computer networking to facilitate the acquisition of interactive competence. System, 22(1), 17-31. doi:10.1016/0346-251X(94)90037-X, http://dx.doi.org/10.1016/0346-251X(94)90037-X

Cobcroft, R., Towers, S., Smith, J., \& Bruns, A. (2006). Mobile learning in review: Opportunities and challenges for learners, teachers, and institutions. Paper presented at Learning on the Move, Brisbane, Australia. [Online] Available: https://olt.qut.edu.au/udf/OLT2006/gen/static/papers/Low_OLT2006_paper.pdf (May 13, 2008).

Creswell, J. (2003). Research design: qualitative, quantitative, and mixed method approaches, $2^{\text {nd }}$ edition. Thousands Oask, CA: Sage.

Friesen, N. (2007). The Microlearning agenda in the age of educational media. In Lindner, M. \& Bruck, P.A. (Eds.), Micromedia and Corporate Learning: Proceedings of the 3rd International Micro-learning 2007 Conference (pp. 63-78). Innsbruck: Innsbruck UP.

Hall, R. (2008). The Impact of the Read/Write Web on Learner Agency. E-Learning, 5(3). 285297.

Hatch,E., \& Farhady, H.(1981). Research design and statistics for applied linguistics. University of California, Los Angles.

Hughes, A. (2003). Testing for language teachers ( $2^{\text {nd }}$ Ed.). Cambridge: Cambridge University Press.

Kern, R. (1995). Restructuring classroom interaction with networked computers: Effects on quality and characteristics of language production. Modern Language Journal, 79(4), 457-476. doi:10.2307/329999, http://dx.doi.org/10.2307/329999

Mason, R. (2008). Can Social Software Change Teaching and Learning? Checkpoint E-learning. [Online] Available: http://www.checkpointelearning. com/article/5813.html (June 11, 2011).

O'Reilly, T. (2005). What is Web 2.0? Design Patterns and Business Models for the Next Generation of Software. O'Reilly Net 30-9-2005. [Online] Available: http://www.oreillynet.com/pub/a/oreilly/tim/news/2005/09/30/what-is-web-20.html (June 11, 2011).

Roschelle, J. (2003). Unlocking the learning value of wireless mobile devices. Journal of Computer Assisted Learning, $\quad 19, \quad 260-272 . \quad$ doi:10.1046/j.0266-4909.2003.00028.x, http://dx.doi.org/10.1046/j.0266-4909.2003.00028.x

Siemens, G. (2005). Connectivism: Learning as Network-Creation. Learning Circuits. [Online] Available: http://www.astd.org/LC/2005/1105_seimens.htm (July 8, 2008).

Underhill, N. (1987). Testing spoken language: A handbook of oral testing techniques. Cambridge: Cambridge University Press.

Warschauer, M. (1996). Comparing face-to-face and electronic discussion in the second language classroom. CALICO Journal, 13(2), 7-26. 